\title{
HYDRAULIC PERFORMANCE OF DRIPPERS APPLYING SANITARY LANDFILL LEACHATE DILUTED IN WATER ${ }^{1}$
}

\author{
HUDSON SALATIEL MARQUES VALE ${ }^{2}$, DANNIELY DE OLIVEIRA COSTA ${ }^{2}$, RAFAEL OLIVEIRA BATISTA ${ }^{2 *}$, \\ DANIELA DA COSTA LEITE COELHO ${ }^{2}$, ALEX PINHEIRO FEITOSA $^{3}$
}

\begin{abstract}
Drip irrigation with diluted sanitary landfill leachate favors the development of grasses on the landfill surface, however, the clogging of emitters of the irrigation systems is the major obstacle for this practice. The objective of this study was to select empirical models of the Christiansen's uniformity coefficient, distribution uniformity coefficient, and statistical uniformity coefficient of drip irrigation sets applying sanitary landfill leachate diluted in water as a function of time of operation, and quality of the effluent. An experiment was conducted in a completely randomized experimental design with three replicates, using a splitsplit plot arrangement, with operating pressures $(70,140,210$, and $280 \mathrm{kPa})$ in the plots, types of drippers $(\mathrm{G} 1$, $1.65 \mathrm{~L} \mathrm{~h}^{-1} ; \mathrm{G} 2,2.0 \mathrm{~L} \mathrm{~h}^{-1}$; and $\left.\mathrm{G} 3,4.0 \mathrm{~L} \mathrm{~h}^{-1}\right)$ in the subplots, and operating time of the drip irrigation sets $(0,20$, $40,60,80,100,120,140$, and 160 hours) in the sub-subplots. Data regarding hydraulic performance and effluent quality were acquired every 20 hours during 160 hours of operation and subjected to simple and multiple regression analyses. The G3 dripper operating at pressures of 70 and $140 \mathrm{kPa}$ were the combinations that best attenuated biofilm clogging. The linear regression and square root were the models that best represented the reduction in the uniformity of the effluent application as a function of the operating time of the drip irrigation sets. The linear correlations denoted that calcium contents and total coliform population rates were the characteristics of the sanitary landfill leachate that most affected the drip clogging process.
\end{abstract}

Keywords: Urban solid waste. Leachate. Emitters. Clogging.

\section{DESEMPENHO HIDRÁULICO DE GOTEJADORES APLICANDO PERCOLADO DE ATERRO SANITÁRIO DILUÍDO EM ÁGUA}

\begin{abstract}
RESUMO - A aplicação localizada de percolado diluído permite o desenvolvimento de gramíneas na superfície das células dos aterros sanitários, entretanto a obstrução dos emissores dos sistemas de irrigação consiste no maior obstáculo desta atividade. Objetivou-se com a realização do presente trabalho selecionar modelos empíricos do coeficiente de uniformidade de Christiansen, coeficiente de uniformidade de distribuição e coeficiente de uniformidade estatístico de unidades gotejadoras aplicando percolado diluído em função do tempo de operação e da qualidade do efluente. Para isso, montou-se um experimento em parcelas subsubdivididas. Nas parcelas tem-se as pressões de serviço (70, 140, 210 e $280 \mathrm{kPa})$, nas subparcelas os tipos de gotejadores (G1 - 1,65 L h $\mathrm{L}^{-1}$ G2 - 2,0 L h $\mathrm{L}^{-1}$; e 4,0 $\mathrm{L} \mathrm{h}^{-1}$ ) e nas subsubparcelas os tempos de operação das unidades gotejadoras $(0,20,40,60,80,100,120,140$ e $160 \mathrm{~h})$. O delineamento experimental foi o inteiramente casualizado com três repetições. Os dados dos indicadores de desempenho hidráulico e da qualidade do efluente foram obtidos a cada $20 \mathrm{~h}$, até completar $160 \mathrm{~h}$ de funcionamento, sendo posteriormente submetidos às análises de regressão simples e múltipla. Os resultados indicaram que o gotejador G3 operando nas pressões de serviço 70 e $140 \mathrm{kPa}$ foram as combinações que melhor atenuaram o entupimento com biofilme. Os modelos de regressão linear e raiz quadrada foram os que melhor representaram a redução da uniformidade de aplicação do efluente em função do tempo de operação nas unidades gotejadoras. As relações lineares revelaram que os teores de cálcio e os níveis populacionais de coliformes totais foram as características do percolado de aterro diluído que mais interferiram no processo de obstrução dos gotejadores.
\end{abstract}

Palavras-chave: Resíduo sólido urbano. Lixiviado. Emissores. Obstrução.

\footnotetext{
${ }^{*}$ Corresponding author

${ }^{1}$ Received for publication in $04 / 13 / 2017$; accepted in $03 / 12 / 2018$.

Paper Extracted from the master dissertation of the first author.

${ }^{2}$ Department of Engineering and Environmental Sciences, Universidade Federal Rural do Semi-Árido, Mossoró, RN, Brazil; klaus_angel@hotmail.com - ORCID: 0000-0002-5391-117X, danniely_oliveira@hotmail.com - 0000-0001-7966-9417, rafaelbatista@ufersa.edu.br - ORCID: 0000-0002-3083-6808,daniela.coelho@ufersa.edu.br - ORCID: 0000-0001-9182-3675.

${ }^{3}$ Multidisciplinary Center Pau dos Ferros, Universidade Federal Rural do Semi-Árido, Pau dos Ferros, RN, Brazil; alex.feitosa@ufersa.edu.br - ORCID: 0000-0001-6480-1593.
} 


\section{INTRODUCTION}

The amount of solid urban waste is increasing rapidly worldwide. Increasing the storage of these wastes in sanitary landfills means increasing production of leachates containing organic and inorganic pollutants that must be treated to reduce their potential impact on groundwater (BHATT et al., 2017).

Sanitary landfill leachate is generated mainly by the infiltration of rainwater, which percolates through layers of urban solid waste and accumulates at the bottom of the landfills. Even though solid waste management practices for sanitary landfills have advanced, the generation of leachate and its management continue to be one of the most important issues associated with sanitary landfills (GUTIERREZ; MATOS; ROSSMANN, 2010; BHATT et al., 2017).

The increase in water demand due to the population growth and productive activities, combined with environmental degradation of water bodies, has caused water scarcity in several regions of the planet. This scarcity is causing changes in population habits, especially in irrigated agriculture areas, with reduction of water consumption and optimization of irrigation systems (SILVA et al., 2012).

Sanitary landfill leachates have high compositional variability; they contain important nutrients (nitrogen, phosphorus, potassium), some micronutrients, and organic matter. Thus, they have a high potential for fertigation of grasses on the landfill surface, minimizing the damages caused by rainfall and surface runoff during rainy periods (MATOS; CARVALHO; AZEVEDO, 2008; SILVA et al., 2011; COELHO et al., 2015).

Drip irrigation systems stand out for application of wastewater due to their greater efficiency in water use $(80 \%$ to $90 \%)$ compared to sprinkler, and surface irrigation systems, reducing contamination of groundwater and plants, and protecting the environment from aerosols (TRIPATHI; RAJPUT; PATEL, 2016).

However, the emitters of drip irrigation systems are highly susceptible to clogging (DURANROS et al., 2009; LIU; HUANG, 2009) due to their physical characteristics (BATISTA et al., 2009), and the presence of physical, chemical, and biological agents in the wastewater (BATISTA et al., 2011a, b; SILVA et al., 2013; MARQUES et al., 2016; MESQUITA et al., 2016a, b).

The biofouling resulting from interactions between microbial secretions and suspended particles is the main cause of clogging of drippers operating with wastewater (OLIVER; HEWA; PEZZANITI, 2014). Mesquita et al. (2016a, b) evaluated sanitary landfill leachate diluted in water and found worms and protozoa in the biofouling of clogged drippers.
Minimizing clogging of drippers by increasing the operating pressure is a technique that does not include the use of chemicals such as inorganic chlorine. According to Silva et al. (2013), Silva et al. (2016), and Batista et al. (2016), operating pressures above $140 \mathrm{kPa}$ reduce clogging rates in pressure-compensating, and non-pressurecompensating emitters.

In this context, the objective of this study was to select empirical models of hydraulic performance of drip irrigation sets applying sanitary landfill leachate diluted in water as a function of time of operation, and quality of the effluent.

\section{MATERIAL AND METHODS}

The experiment was carried out from March 18 to May 14, 2014, at the Experimental Unit for Water Reuse of the Federal Rural University of the Semi-Arid Region, in Mossoró RN, Brazil (512'27"S; 37¹9'21"W).

The experiment was conducted in a completely randomized experimental design with three replicates, using a split-split plot arrangement, with operating pressures $(70,140,210$, and $280 \mathrm{kPa})$ in the plots, types of drippers $\left(\mathrm{G} 1,1.65 \mathrm{~L} \mathrm{~h}^{-1} ; \mathrm{G} 2\right.$, $2.0 \mathrm{~L} \mathrm{~h}^{-1}$; and $\mathrm{G} 3,4.0 \mathrm{~L} \mathrm{~h}^{-1}$ ) in the subplots, and operating time of the drip irrigation sets $(0,20,40$, $60,80,100,120,140$, and 160 hours) in the sub-subplots.

The drippers used in this experiment $(\mathrm{G} 1, \mathrm{G} 2$, and G3) were chosen because they are among the most used drippers in the Mossoró region. The interval between evaluations (20 hours), and total operating time (160 hours) were chosen based on the works of Batista et al. (2013), and Silva et al. (2013), who reported these operating times as sufficient to detect the effect of emitter clogging on the hydraulic performance of drip irrigation sets operating with wastewater.

An experimental bench with an effluent recirculation system was set up following the technical recommendations of Silva et al. (2013). It consisted in a $16 \mathrm{~m}^{3}$ reservoir for public water with a motor pump of $0.5 \mathrm{cv}$; two $0.55 \mathrm{~m}^{3}$ reservoir for sanitary landfill leachate; a $5.0 \mathrm{~m}^{3}$ tank for the diluted effluent; a platform with a channel; four drip irrigation sets at operating pressures of 70, 140, 210, and $280 \mathrm{kPa}$; a motor pump of $0.5 \mathrm{cv}$; a motor pump of $1.0 \mathrm{cv}$; and two screen filters with mesh of 130 $\mu \mathrm{m} 9$ (Figure 1).

Each drip irrigation set contained an analog glycerin manometer, a gate valve to control the operating pressures $(70,140,210$ and $280 \mathrm{kPa})$ (SILVA et al., 2013), a main line consisted of a polyvinyl chloride tube with internal diameter of $32 \mathrm{~mm}$, and nine 8-m lateral lines connected to this main line containing three types of drippers (Table 1). 
H. S. M. VALE et al.

Table 1. Characteristics of the drippers used in the experimental tests.

\begin{tabular}{lcccccc}
\hline \multicolumn{1}{c}{ Drippers } & $\begin{array}{c}\text { Pressure- } \\
\text { compensating* }\end{array}$ & $\begin{array}{c}\text { Flow* } \\
\left(\mathrm{L} \mathrm{h}^{-1}\right)\end{array}$ & $\begin{array}{c}\text { Filtering } \\
\text { area }\left(\mathrm{mm}^{2}\right)\end{array}$ & $\begin{array}{c}\text { Labyrint } \\
\text { h length } \\
(\mathrm{mm})\end{array}$ & $\begin{array}{c}\text { Pressure } \\
(\mathrm{kPa})\end{array}$ & $\begin{array}{c}\text { Dripper } \\
\text { spacing }(\mathrm{m})\end{array}$ \\
\hline G1 - Plastro Hydrodrip Super & No & 1.65 & $4.0^{* *}$ & $37^{* *}$ & $60-150$ & 0.30 \\
G2 - Netafim Tiran & No & 2.00 & $70.0^{*}$ & $75^{*}$ & $100-300$ & 0.40 \\
G3 - Netafim PCJ-CNJ & Yes & 4.00 & $2.0^{*}$ & $35^{*}$ & $50-400$ & 0.70 \\
\hline
\end{tabular}

*Based on the manufacturer's information; **Based on measurements with a precision $(0.01 \mathrm{~mm})$ digital caliper.

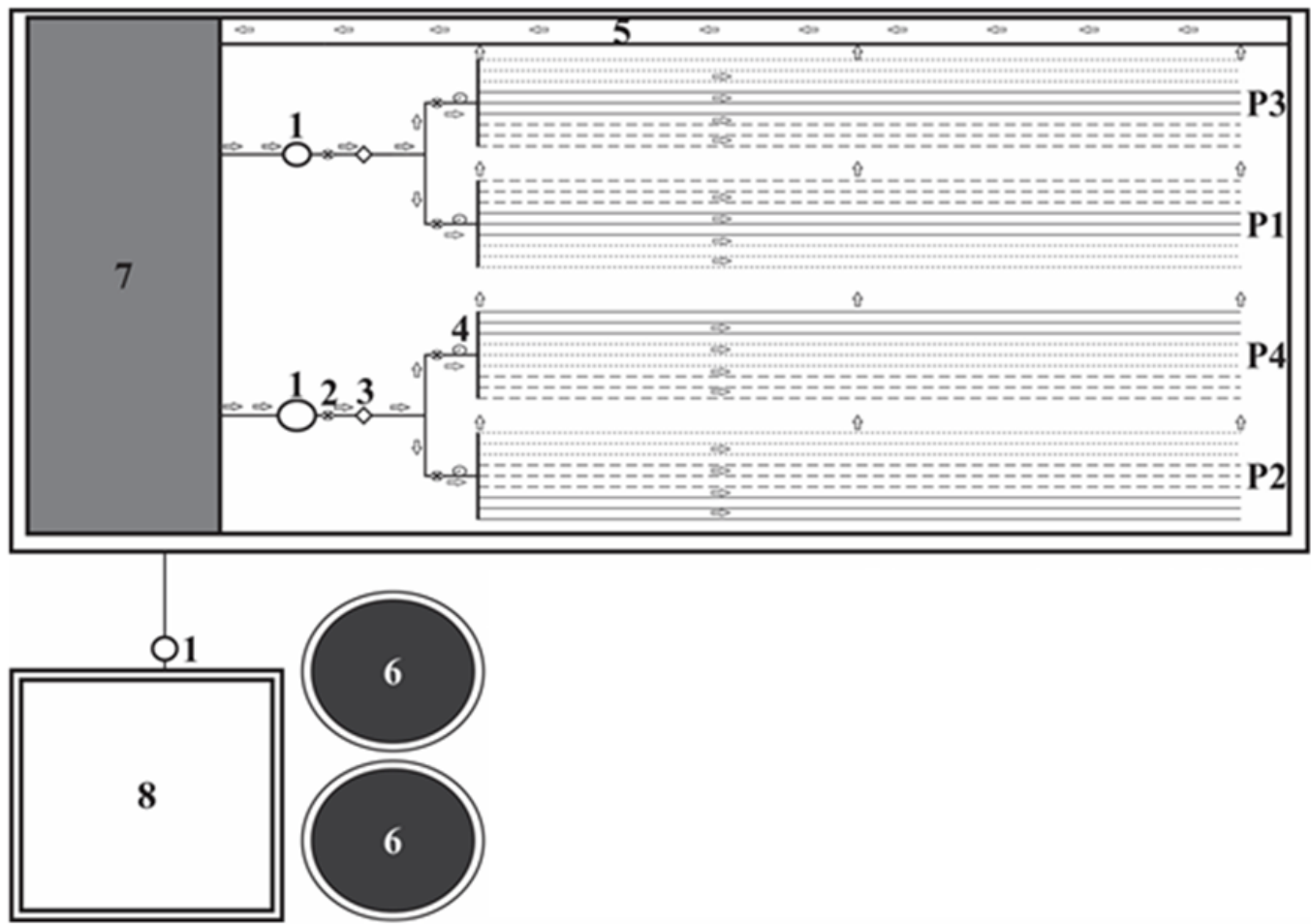

*1 - Motor pump, 2 - Valve, 3 - Screen filter, 4 - Manometer, 5 - Channel, 6 - Reservoir for sanitary landfill leachate, 7 - Tank for the diluted effluent, 8 - Reservoir for public water, P1 - Drip unit operating with $70 \mathrm{kPa}$, P2 - Drip unit operating with $140 \mathrm{kPa}$, P3 - Drip unit operating with $210 \mathrm{kPa}$, P4 - Drip unit operating with $280 \mathrm{kPa}$, - Dripper G1 $\left(1.6 \mathrm{~L} \mathrm{~h}^{-1}\right)$, - Dripper G2 $\left(2.0 \mathrm{~L} \mathrm{~h}^{-1}\right)$ and -- Dripper G3 $\left(4.0 \mathrm{~L} \mathrm{~h}^{-1}\right)$.

Figure 1. Experimental bench layout.

Sanitary landfill leachate from the landfill of Mossoró was diluted with water from the Rio Grande do Norte Water Company (CAERN), in a proportion of 1:3-one part of landfill leachate and three parts of water-in the effluent tank, following the recommendation of Mesquita et al. (2016a, b). The diluted landfill leachate presented electrical conductivity close to the limit of $3.0 \mathrm{dS} \mathrm{m} \mathrm{m}^{-1}$ established by the Resolution no. 2/2017 of COEMA (CEARÁ, 2017) for water reuse on agriculture and forestry. Moreover, the dilution decreased its viscosity; the high viscosity of the raw sanitary landfill leachate could generate overheating problems in the pumps.

Ten drippers were equidistantly set in each of the 36 lateral lines to evaluate their hydraulic performance. The evaluated drippers were marked with ink to facilitate the measurement of the flow, according to the normalization NBR ISO 9261 (ABNT, 2006). The applied volume was quantified by collecting the effluent using a $100 \mathrm{~mL}$ beaker with an accuracy of $1 \mathrm{~mL}$ for three minutes. The flow of each dripper was calculated by Equation 1,

$$
\mathrm{q}_{\mathrm{i}}=\frac{\mathrm{vol}}{1000 \cdot \mathrm{t}} \cdot 60
$$

wherein $q i$ is the flow of each emitter $\left(\mathrm{L} \mathrm{h}^{-1}\right)$, vol is the volume of effluent collected in each emitter $(\mathrm{mL})$; and $\mathrm{t}$ is the collecting time of the effluent in each emitter (min).

The uniformity of the effluent application in the drippers were obtained by the Christiansen's uniformity coefficient (CUC), distribution uniformity coefficient (DUC), and statistical uniformity coefficient (SUC), using Equations 2, 3, and 4 , respectively, 


$$
\mathrm{CUC}=100 \cdot\left(1-\frac{\sum_{\mathrm{i}=1}^{\mathrm{n}}\left|\mathrm{q}_{\mathrm{i}}-\overline{\mathrm{q}}\right|}{\mathrm{n}_{\mathrm{e}} \cdot \overline{\mathrm{q}}}\right)
$$

wherein $q i$ is the flow of each emitter $\left(\mathrm{L} \mathrm{h}^{-1}\right), q$ is the average flow of emitters $\left(\mathrm{L} \mathrm{h}^{-1}\right)$, and $n_{e}$ is the number of emitters evaluated in the drip irrigation sets;

$$
\mathrm{CUD}=100 \cdot \frac{\mathrm{q}_{25 \%}}{\overline{\mathrm{q}}}
$$

wherein $q_{25 \%}$ is the mean of the $25 \%$ lower flow rates of the emitters $\left(\mathrm{L} \mathrm{h}^{-1}\right)$, and $q$ is the average flow of the emitters in the drip irrigation sets $\left(\mathrm{L} \mathrm{h}^{-1}\right)$;

$$
\mathrm{U}_{\mathrm{s}}=100 \cdot(1-\mathrm{CVQ})
$$

wherein $C V F$ is the coefficient of variation of the flow in the dripper, decimal.

The coefficient of variation in the manufacturing of the drippers did not exceeded the limit of $\pm 7 \%$, established in NBR ISO 9261 (ABNT, 2006) in any drip irrigation set.

CUC, DUC, and SUC were evaluated every 20 hours, with the drip irrigation sets running, on average, five hours a day for 160 hours, to detect the clogging rates of the emitters applying sanitary landfill leachate diluted in water, as recommended by Mesquita et al. (2016a, b).

Samples of the sanitary landfill leachate were collected for physical, chemical, and microbiological characterization (Table 2), following the criteria of the Standard Methods for the Examination of Water and Wastewater (RICE; BAIRD; CLESCERI, 2012). The suspended solids (SS), pH, dissolved solids (DS), $\mathrm{Ca}^{2+}, \mathrm{Fe}, \mathrm{Mn}, \mathrm{Mg}^{2+}$, and total coliforms (TC) were evaluated.

\begin{tabular}{|c|c|c|c|c|c|c|c|c|c|}
\hline & \multicolumn{9}{|c|}{ Operating time (hours) } \\
\hline & 0 & 20 & 40 & 60 & 80 & 100 & 120 & 140 & 160 \\
\hline $\mathrm{pH}$ & 9.30 & 9.20 & 8.96 & 8.76 & 9.15 & 8.79 & 8.85 & 8.98 & 9.43 \\
\hline Electric conductivity $\left(\mathrm{dS} \mathrm{m}^{-1}\right)$ & 3.95 & 3.98 & 3.51 & 3.93 & 3.21 & 3.71 & 3.45 & 4.40 & 4.06 \\
\hline Suspended solids (mg L $\left.{ }^{-1}\right)$ & 228 & 282 & 408 & 514 & 537 & 576 & 496 & 556 & 571 \\
\hline Dissolved solids (mg L $\mathrm{L}^{-1}$ ) & 2963 & 2985 & 2633 & 2948 & 2408 & 2783 & 2588 & 3608 & 3329 \\
\hline $\mathrm{Fe}\left(\mathrm{mg} \mathrm{L}^{-1}\right)$ & 3.09 & 3.60 & 2.25 & 1.81 & 1.35 & 1.13 & 1.09 & 1.96 & 1.86 \\
\hline $\operatorname{Mn}\left(\mathrm{mg} \mathrm{L}^{-1}\right)$ & 0.12 & 0.10 & 0.07 & 0.08 & 0.03 & 0.06 & 0.04 & 0.05 & 0.06 \\
\hline $\mathrm{Ca}^{2+}\left(\mathrm{mmol}_{\mathrm{c}} \mathrm{L}^{-1}\right)$ & 8.50 & 7.00 & 4.80 & 6.17 & 8.50 & 6.60 & 6.60 & 9.10 & 11.90 \\
\hline $\mathrm{Mg}^{2+}\left(\mathrm{mmol}_{\mathrm{c}} \mathrm{L}^{-1}\right)$ & 5.60 & 9.80 & 9.80 & 9.63 & 8.40 & 6.90 & 4.40 & 4.50 & 13.90 \\
\hline Total coliforms (MPN $100 \mathrm{~mL}^{-1}$ ) & 23 & 9.2 & 23 & 23 & 3 & 240 & 23 & 1100 & 1100 \\
\hline
\end{tabular}

Table 2. Physical, chemical, and microbiological characteristics of the sanitary landfill leachate diluted in water used during the operating period of the drip irrigation sets.

MPN $=$ most probable number

After the end of the experimental tests (160 hours), the lateral lines were cut, and the drippers were opened to photograph the biofilms.

The CUC, DUC, and SUC data were subjected to analysis of variance (ANOVA) and regression analysis. ANOVA was obtained by the $\mathrm{F}$ test with probability levels of $1 \%$ and $5 \%$. The regression models were chosen based on the significance of the regression coefficients, applying the $t$ test to a level of $10 \%$, in the coefficient of determination $(>60 \%)$, and in the study process.

\section{RESULTS AND DISCUSSION}

The operating time $(\mathrm{T}) \mathrm{x}$ pressure $(\mathrm{P}) \mathrm{x}$ type of dripper (G) interaction, and the $\mathrm{T}$ and $\mathrm{P}$ interaction were not significant $(p>0.05 \%)$ for any of the studied variables; and the $\mathrm{G}$ and $\mathrm{T}$ factors, and the $\mathrm{TxG}$ interaction were significant $(p<0.01)$ (Table $3)$. The $\mathrm{P}$ factor was significant $(p<0.01)$ for CUC and SUC, and the GxP interaction was significant $(p<0.05)$ for CUC. These results differ from those found by Batista et al. (2013) and Silva et al. (2013), who found significance $(p<0.01)$ for all interactions and factors.

The interaction between some factors was not significant due to processes of random unclogging of emitters, sudden movements affecting the lateral lines during the hydraulic performance evaluation, and the detachment of fragments of the biofilm by hydraulic forces. The dynamics of clogging evaluated in this work allowed an increase in the flow of the drippers because of the physicochemical composition of the sanitary landfill leachate used. Moreover, the hydraulic performance of drip irrigation sets operating with wastewater is 
compromised due to the formation of biofilm inside the emitters and lateral lines (BATISTA et al., 2008; YAN et al., 2009; LI et al., 2011; SILVA et al., 2013; BATISTA; OLIVEIRA; MESQUITA, 2014; MARQUES et al., 2016; MESQUITA et al., 2016a, b).

All coefficients of variation were low $(<10 \%)$, indicating that the CUC, DUC, and SUC data of the drippers were collected with high precision (PIMENTEL GOMES, 2009).

Table 3. Analysis of variance of the variables for the Christiansen's uniformity coefficient (CUC), distribution uniformity coefficient (DUC), and statistical uniformity coefficient (SUC) evaluated in a split-split plot arrangement, and their respective coefficients of variation $(\mathrm{CV})$.

\begin{tabular}{lcccc}
\hline \multirow{2}{*}{ Source of Variation } & $\begin{array}{c}\text { Degrees of } \\
\text { Freedom }\end{array}$ & CUC & DUC & SUC \\
\cline { 3 - 5 } & 3 & $14.80^{*}$ & $84.31^{\text {ns }}$ & $29.31^{*}$ \\
\hline Pressures (P) & 6 & 4.30 & 45.61 & 8.48 \\
\hline Residue (a) & 2 & $89.74^{* *}$ & $578.71^{* *}$ & $226.00^{* *}$ \\
\hline Type of drippers (G) & 6 & $15.36^{*}$ & $84.10^{\text {ns }}$ & $28.07^{\text {ns }}$ \\
GxP & 16 & 7.15 & 52.58 & 16.08 \\
\hline Residue (b) & 8 & $32.86^{* *}$ & $167.58^{* *}$ & $66.59^{* *}$ \\
\hline Operating time (T) & 24 & $1.71^{\text {ns }}$ & $9.37^{\text {ns }}$ & $3.27^{\text {ns }}$ \\
TxP & 16 & $6.58^{* *}$ & $33.55^{* *}$ & $12.93^{* *}$ \\
TxG & 48 & $2.55^{\text {ns }}$ & $13.88^{\text {ns }}$ & $5.27^{\text {ns }}$ \\
TxPxG & 194 & & & \\
\hline Residue (c) & & 2.14 & 7.19 & 3.05 \\
\hline CV plot (\%) & & 2.76 & 7.72 & 4.20 \\
CV subplot (\%) & & 1.45 & 3.67 & 2.32 \\
CV sub-subplot (\%) & & 96.83 & 93.95 & 95.61 \\
\hline Mean (\%) & & &
\end{tabular}

$* *$ significant at $1 \%, *$ significant at $5 \%$, and ${ }^{\mathrm{ns}}$ not significant at $5 \%$ probability by the $\mathrm{F}$ test.

The diluted landfill leachate formed a dark brown biofilm in the labyrinth openings and secondary filters of the drippers after 160 hours of operation (Figure 2). This caused alterations in the CUC, DUC, and SUC of the drip irrigation sets, as evidenced in the analysis of variance (Table 3 ). Mesquita et al. (2016a, b) found formation of a dark brown biofilm inside emitters applying diluted landfill leachate, with higher adhesion of the biofilm to the filtration area and pressure-compensating membrane chamber.

A.

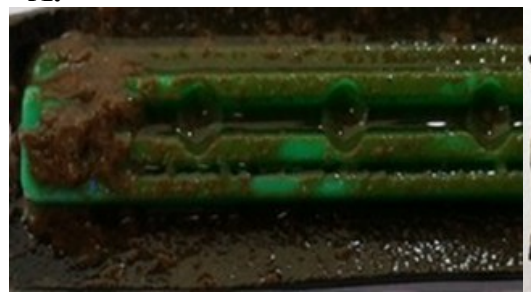

B.

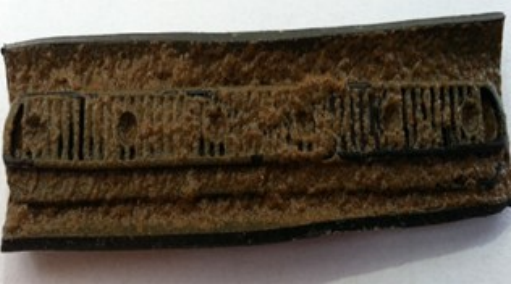

The regression equations fitted to the variables CUC, DUC, and SUC as a function of the operating times of the drip irrigation sets for the combinations between types of drippers and operating pressures are presented in Table 4. The combinations G1xP1, G2xP1, G1xP2, and G2xP3 showed significant changes for the CUC as a function of T. After 160 hours of operation of the drip irrigation sets, the lower $(92.89 \%)$ and higher (98.29\%) CUC was found in the combinations $\mathrm{G} 2 \times \mathrm{P} 1$ and $\mathrm{G} 3 \times \mathrm{P} 1$, respectively.

Figure 2. Images of the biofilm formed inside the G1 (A), G2 (B), and G3 (C) drippers that applied diluted landfill leachate for 160 hours.

The square root regression model had best fit for the combinations $\mathrm{G} 1 \mathrm{xP} 2$ and $\mathrm{G} 2 \mathrm{xP} 3$ regarding CUC as a function of $\mathrm{T}$; the linear model had the best fit for the combinations G1xP1 and G2xP1; and no significant effect of $\mathrm{T}$ on the CUC data was found for the other combinations, which had the mean as best representation of the data. Batista et al. (2009) evaluated drip irrigation sets with three types of emitters applying tertiary domestic wastewater for 560 hours and found linear correlation between CUC 
and $\mathrm{T}$.

The DUC data as a function of $\mathrm{T}$ showed the linear regression model as the best fit for the combinations G1xP1 and G1xP2. The square root model was the best fit for the combination G2xP3. No significant changes in DUC as a function of $\mathrm{T}$ were found for the other combinations, indicating a higher resistance to clogging, with the mean as the best representation of the data. The lowest $(83.66 \%)$ and highest $(97.35 \%)$ DUC were found for the combinations $\mathrm{G} 2 \mathrm{xP} 1$ and $\mathrm{G} 3 \times \mathrm{P} 1$, respectively, at 160 hours of operation of the drip irrigation sets.

Table 4. Regression equations fitted to the CUC, DUC, and SUC as a function of the operating times of the drip irrigation sets $(\mathrm{T})$ for the combinations between dripper types $(\mathrm{G})$ and operating pressures $(\mathrm{P})$.

\begin{tabular}{|c|c|c|c|}
\hline Combination & Specification & Regression equation & $\mathrm{R}^{2}$ \\
\hline \multicolumn{4}{|c|}{ CUC } \\
\hline 1 & G1xP1 & $\widehat{C U C}=97.99-0.027^{* *} \mathrm{~T}$ & 0.81 \\
\hline 2 & $\mathrm{G} 2 \mathrm{xP} 1$ & $\widehat{C U C}=97.66-0.030^{* *} \mathrm{~T}$ & 0.71 \\
\hline 3 & G3xP1 & $\widehat{\mathrm{CUC}}=\overline{\mathrm{CUC}}=98.29$ & - \\
\hline 4 & $\mathrm{G} 1 \mathrm{xP} 2$ & $\widehat{C U C}=98.25+0.42^{*} \mathrm{~T}^{0.5}-0.061^{* *} \mathrm{~T}$ & 0.92 \\
\hline 5 & $\mathrm{G} 2 \mathrm{xP} 2$ & $\widehat{C U C}=\overline{\mathrm{CUC}}=97.69$ & - \\
\hline 6 & $\mathrm{G} 3 \mathrm{xP} 2$ & $\widehat{\mathrm{CUC}}=\overline{\mathrm{CUC}}=97.79$ & - \\
\hline 7 & G1xP3 & $\widehat{\mathrm{CUC}}=\overline{\mathrm{CUC}}=96.24$ & - \\
\hline 8 & $\mathrm{G} 2 \mathrm{xP} 3$ & $\widehat{C U C}=96.370+0.69^{* *} \mathrm{~T}^{0.5}-0.064^{* *} \mathrm{~T}$ & 0.88 \\
\hline 9 & G3xP3 & $\widehat{\mathrm{CUC}}=\overline{\mathrm{CUC}}=97.63$ & - \\
\hline 10 & G1xP4 & $\widehat{\mathrm{CUC}}=\overline{\mathrm{CUC}}=96.59$ & - \\
\hline 11 & $\mathrm{G} 2 \mathrm{xP} 4$ & $\widehat{\mathrm{CUC}}=\overline{\mathrm{CUC}}=95.23$ & - \\
\hline 12 & $\mathrm{G} 3 \mathrm{xP} 4$ & $\widehat{\mathrm{CUC}}=\overline{\mathrm{CUC}}=97.82$ & - \\
\hline \multicolumn{4}{|c|}{ DUC } \\
\hline 1 & G1xP1 & $\widehat{\mathrm{DUC}}=97.81-0.063^{* *} \mathrm{~T}$ & 0.89 \\
\hline 2 & $\mathrm{G} 2 \mathrm{xP} 1$ & $\widehat{\mathrm{DUC}}=\overline{\mathrm{DUC}}=89.71$ & - \\
\hline 3 & $\mathrm{G} 3 \mathrm{xP} 1$ & $\widehat{\mathrm{DUC}}=\overline{\mathrm{DUC}}=97.35$ & - \\
\hline 4 & $\mathrm{G} 1 \times \mathrm{P} 2$ & $\widehat{\mathrm{DUC}}=99.68-0.078^{* *} \mathrm{~T}$ & 0.87 \\
\hline 5 & $\mathrm{G} 2 \mathrm{xP} 2$ & $\widehat{\mathrm{DUC}}=\overline{\mathrm{DUC}}=95.61$ & - \\
\hline 6 & $\mathrm{G} 3 \mathrm{xP} 2$ & $\widehat{\mathrm{DUC}}=\overline{\mathrm{DUC}}=96.33$ & - \\
\hline 7 & G1xP3 & $\widehat{\mathrm{DUC}}=\overline{\mathrm{DUC}}=93.49$ & - \\
\hline 8 & $\mathrm{G} 2 \mathrm{xP} 3$ & $\widehat{\mathrm{DUC}}=92.03+1.69^{* *} \mathrm{~T}^{0.5}-0.15^{* *} \mathrm{~T}$ & 0.89 \\
\hline 9 & $\mathrm{G} 3 \mathrm{xP} 3$ & $\widehat{\mathrm{DUC}}=\overline{\mathrm{DUC}}=96.32$ & - \\
\hline 10 & G1xP4 & $\widehat{\mathrm{DUC}}=\overline{\mathrm{DUC}}=93.07$ & - \\
\hline 11 & $\mathrm{G} 2 \mathrm{xP} 4$ & $\widehat{\mathrm{DUC}}=\overline{\mathrm{DUC}}=89.54$ & - \\
\hline 12 & $\mathrm{G} 3 \mathrm{xP} 4$ & $\widehat{\mathrm{DUC}}=\overline{\mathrm{DUC}}=96.21$ & - \\
\hline \multicolumn{4}{|c|}{ SUC } \\
\hline 1 & G1xP1 & $\widehat{\mathrm{SUC}}=97.12-0.036^{* *} \mathrm{~T}$ & 0.75 \\
\hline 2 & $\mathrm{G} 2 \mathrm{xP} 1$ & $\widehat{\mathrm{SUC}}=96.64-0.042^{* *} \mathrm{~T}$ & 0.70 \\
\hline 3 & $\mathrm{G} 3 \mathrm{xP} 1$ & $\widehat{\mathrm{SUC}}=\overline{\mathrm{SUC}}=97.85$ & - \\
\hline 4 & $\mathrm{G} 1 \mathrm{xP} 2$ & $\widehat{\mathrm{SUC}}=98.99-0.045^{* *} \mathrm{~T}$ & 0.82 \\
\hline 5 & $\mathrm{G} 2 \mathrm{xP} 2$ & $\widehat{\mathrm{SUC}}=\overline{\mathrm{SUC}}=96.64$ & - \\
\hline 6 & $\mathrm{G} 3 \mathrm{xP} 2$ & $\widehat{\mathrm{SUC}}=\overline{\mathrm{SUC}}=97.17$ & - \\
\hline 7 & G1xP3 & $\widehat{\mathrm{SUC}}=\overline{\mathrm{SUC}}=94.99$ & - \\
\hline 8 & $\mathrm{G} 2 \mathrm{xP} 3$ & $\widehat{\mathrm{SUC}}=94.75+0.97^{* *} \mathrm{~T}^{0.5}-0.091^{* *} \mathrm{~T}$ & 0.82 \\
\hline 9 & $\mathrm{G} 3 \mathrm{xP} 3$ & $\widehat{\mathrm{SUC}}=\overline{\mathrm{SUC}}=96.95$ & - \\
\hline 10 & G1xP4 & $\widehat{\mathrm{SUC}}=\overline{\mathrm{SUC}}=95.13$ & - \\
\hline 11 & $\mathrm{G} 2 \mathrm{xP} 4$ & $\widehat{\mathrm{SUC}}=\overline{\mathrm{SUC}}=93.24$ & - \\
\hline 12 & $\mathrm{G} 3 \mathrm{xP} 4$ & $\widehat{\mathrm{SUC}}=\overline{\mathrm{SUC}}=97.14$ & - \\
\hline
\end{tabular}

**significant at $1 \%$, and *significant at $5 \%$ probability by the $\mathrm{t}$ test. 
Batista et al. (2011a) found linear correlation between DUC and T for drip irrigation sets operating with tertiary domestic wastewater for 500 hours. In another study, Batista et al. (2013) found quadratic regression model as the best fit for DUC and T data in drip irrigation sets with three types of emitters applying swine effluent for 2 hours followed by 2 hours of application of public water, for 160 hours. Silva et al. (2016) evaluated drip irrigation sets with three types of emitters applying castor nut wastewater at pressures of $70,140,210$ and $280 \mathrm{kPa}$ for 160 hours and found linear regression, square root, and quadratic models as the best fit the reduction of DUC as a function of $\mathrm{T}$.

The $\mathrm{T}$ factor affected the SUC, indicating clogging in the drippers. After 160 hours of operation of the drip irrigation sets, the lowest (89.97\%) and highest (97.85\%) SUC was found in the combinations $\mathrm{G} 2 \times \mathrm{P} 1$ and $\mathrm{G} 3 \mathrm{xP} 1$, respectively. The linear regression model had the best fit for the combinations G1xP1, G2xP1 and G1xP2. The square root model had the best fit for the $\mathrm{G} 2 \times \mathrm{PP} 3$ combination. No significant effect of $\mathrm{T}$ on the SUC was found for the other combinations, with the mean presenting the best representation of the data. Batista et al. (2011a) also found linear correlation for SUC and $\mathrm{T}$ data in drip irrigation sets operating with primary and tertiary domestic wastewater. Batista et al. (2016) found linear regression, square root, and quadratic models as the best fit to the SUC as a function of $\mathrm{T}$ for drip irrigation sets with three types of emitters operating with swine effluent at pressures of $70,140,210$ and $280 \mathrm{kPa}$ for 160 hours

The results of CUC, DUC, and SUC for the operating time of 160 hours showed that the dripper G2 operating at operating pressure P1 was more susceptible to clogging. This was probably due to its longer labyrinth length $(75 \mathrm{~mm})$, which favors the development of biofilms in its sections of lower effluent flow, confirming the reports of Dazhuang et al. (2009) and Batista et al. (2009). Moreover, the operating pressure used $(70 \mathrm{kPa})$ was below the recommended range by the manufacturer (100-300 $\mathrm{kPa})$.

The lowest clogging and highest CUC, DUC, and SUC after 160 hours, was found in the G3 drippers at operating pressure of $70 \mathrm{kPa}$. This result is attributed to the higher flow rate of this type of dripper compared to G1 and G2. In addition, the G3 dripper has labyrinth with large sections for effluent flow, hindering the sedimentation of particles and biofilm adhesion, increasing its resistance to clogging. Batista et al. (2013) evaluated three types of drippers applying swine effluent for 160 hours and found similar results, with pressure-compensating emitters presenting less susceptibility to biofilm clogging than non-pressure-compensating emitters.

The multiple linear regression equations fitted to CUC, DUC, and SUC as a function of the physical (SS), chemical ( $\mathrm{pH}, \mathrm{DS}, \mathrm{Ca}^{2+}, \mathrm{Fe}, \mathrm{Mn}, \mathrm{Mg}^{2+}$ ), and microbiological (TC) characteristics of the diluted landfill leachate for combinations of dripper types (G) and operating pressures (P) (Table 5). Only the $\mathrm{Ca}^{2+}$ content and TC presented linear correlations with CUC and DUC. Silva et al. (2016) found different results with drip irrigation sets operating with cashew nut wastewater at operating pressure of $70 \mathrm{kPa}$, presenting linear correlation of $\mathrm{Mg}^{2+}, \mathrm{DS}$, and TC with DUC.

The $\mathrm{Ca}^{2+}$ and TC affected the CUC in G1xP2, and $\mathrm{Ca}^{2+}$ affected the CUC in G2xP3. TC and $\mathrm{Ca}^{2+}$ affected significantly the DUC in G1xP2. It shows linear, and multiple linear correlations of the $\mathrm{Ca}^{2+}$ and $\mathrm{TC}$ with clogging rates for $\mathrm{G} 1 \mathrm{xP} 2$ and $\mathrm{G} 2 \mathrm{xP} 3$. $\mathrm{Ca}^{2+}$ probably formed $\mathrm{CaCO}_{3}$ precipitates, and TC formed bacterial mucilage inside the drippers. These results agree with those found by Eroglu et al. (2012), who found $\mathrm{CaCO}_{3}$ in clogged drippers by low quality water. Moreover, Dazhuang et al. (2009) found biofilm formation in clogged drippers due to interaction between bacterial mucilage and particulate matter.

No linear correlation between physical, chemical, and microbiological characteristics was found for SUC in any of the 12 combinations tested. Contrastingly, Capra and Scicolone (1998) found linear correlation of total iron and bicarbonate with SUC, in irrigation sets with clogging problems.

The SUC hydraulic performance indicator showed better results for the detection of clogging in drip irrigation sets applying diluted landfill leachate than CUC and DUC. The flow oscillations in the SUC are obtained by the standard deviation of the data, thus, the results are less affected by totally clogged drippers and flow increases; while in the DUC, the relation between the $25 \%$ lower flows and average flow generates overestimated clogging rates, especially when there are completely clogged emitters; and in the CUC, clogging rates are underestimated because of the mean deviation and average flows. 
Table 5. Regression equations fitted to CUC, DUC, and SUC as a function of the physical (SS), chemical (pH, DS, $\mathrm{Ca}^{2+}$, $\mathrm{Fe}, \mathrm{Mn}, \mathrm{Mg}^{2+}$ ) and microbiological (TC) characteristics of the diluted landfill leachate for combinations of dripper types $(\mathrm{G})$ and operating pressures $(\mathrm{P})$.

\begin{tabular}{|c|c|c|c|}
\hline Combination & Specification & Regression equation & $\mathrm{R}^{2}$ \\
\hline \multicolumn{4}{|c|}{ CUC } \\
\hline 1 & G1xP1 & $\widehat{\mathrm{CUC}}=\overline{\mathrm{CUC}}=95.67$ & - \\
\hline 2 & $\mathrm{G} 2 \mathrm{xP} 1$ & $\widehat{\mathrm{CUC}}=\overline{\mathrm{CUC}}=95.22$ & - \\
\hline 3 & G3xP1 & $\widehat{\mathrm{CUC}}=\overline{\mathrm{CU}} \overline{\mathrm{C}}=98.33$ & - \\
\hline 4 & $\mathrm{G} 1 \mathrm{xP} 2$ & $\widehat{C U C}=101.66-0.31^{* * *} \mathrm{Ca}^{2+}-1.51^{* *} \mathrm{TC}$ & 0.81 \\
\hline 5 & $\mathrm{G} 2 \mathrm{xP} 2$ & $\widehat{\mathrm{CUC}}=\overline{\mathrm{CUC}}=97.78$ & - \\
\hline 6 & $\mathrm{G} 3 \mathrm{xP} 2$ & $\widehat{\mathrm{CUC}}=\overline{\mathrm{CUC}}=97.89$ & - \\
\hline 7 & G1xP3 & $\widehat{\mathrm{CUC}}=\overline{\mathrm{CUC}}=96.11$ & - \\
\hline 8 & $\mathrm{G} 2 \mathrm{xP} 3$ & $\widehat{\mathrm{CUC}}=\overline{\mathrm{DUC}}=96.79$ & - \\
\hline 9 & G3xP3 & $\widehat{\mathrm{CUC}}=\overline{\mathrm{CUC}}=97.67$ & - \\
\hline 10 & G1xP4 & $\widehat{C U C}=\overline{\mathrm{CUC}}=96.67$ & - \\
\hline 11 & $\mathrm{G} 2 \mathrm{xP} 4$ & $\widehat{\mathrm{CUC}}=\overline{\mathrm{CU}} \overline{\mathrm{C}}=95.11$ & - \\
\hline 12 & $\mathrm{G} 3 \mathrm{xP} 4$ & $\widehat{\mathrm{CUC}}=\overline{\mathrm{CU}} \overline{\mathrm{C}}=97.78$ & - \\
\hline \multicolumn{4}{|c|}{ DUC } \\
\hline 1 & G1xP1 & $\widehat{\mathrm{DUC}}=\overline{\mathrm{DUC}}=92.67$ & - \\
\hline 2 & $\mathrm{G} 2 \mathrm{xP} 1$ & $\widehat{\mathrm{DUC}}=\overline{\mathrm{DUC}}=89.78$ & - \\
\hline 3 & $\mathrm{G} 3 \times \mathrm{P} 1$ & $\widehat{\mathrm{DUC}}=\overline{\mathrm{DUC}}=97.44$ & - \\
\hline 4 & $\mathrm{G} 1 \mathrm{xP} 2$ & $\widehat{\mathrm{DUC}}=100.61-4.20^{* *} \mathrm{TC}$ & 0.67 \\
\hline 5 & $\mathrm{G} 2 \mathrm{xP} 2$ & $\widehat{\mathrm{DUC}}=\overline{\mathrm{DUC}} \overline{\mathrm{C}}=95.44$ & - \\
\hline 6 & $\mathrm{G} 3 \mathrm{xP} 2$ & $\widehat{\mathrm{DUC}}=\overline{\mathrm{DUC}}=96.33$ & - \\
\hline 7 & G1xP3 & $\widehat{\mathrm{DUC}}=\overline{\mathrm{DUC}}=93.56$ & - \\
\hline 8 & $\mathrm{G} 2 \mathrm{xP} 3$ & $\widehat{\mathrm{DUC}}=102.18-1.12^{* *} \mathrm{Ca}^{2+}$ & 0.68 \\
\hline 9 & $\mathrm{G} 3 \mathrm{xP} 3$ & $\widehat{\mathrm{DUC}}=\overline{\mathrm{DUC}}=96.44$ & - \\
\hline 10 & G1xP4 & $\widehat{\mathrm{DUC}}=\overline{\mathrm{DUC}}=93.22$ & - \\
\hline 11 & $\mathrm{G} 2 \mathrm{xP} 4$ & $\widehat{\mathrm{DUC}}=\overline{\mathrm{DUC}}=89.56$ & - \\
\hline 12 & $\mathrm{G} 3 \mathrm{xP} 4$ & $\widehat{\mathrm{DUC}}=\overline{\mathrm{DUC}}=96.22$ & - \\
\hline \multicolumn{4}{|c|}{ SUC } \\
\hline 1 & G1xP1 & $\widehat{\mathrm{SUC}}=\overline{\mathrm{SU}} \overline{\mathrm{U}}=94.22$ & - \\
\hline 2 & $\mathrm{G} 2 \mathrm{xP} 1$ & $\widehat{\mathrm{SUC}}=\overline{\mathrm{SUC}}=93.33$ & - \\
\hline 3 & $\mathrm{G} 3 \mathrm{xP} 1$ & $\widehat{\mathrm{SUC}}=\overline{\mathrm{SU}} \overline{\mathrm{C}}=97.89$ & - \\
\hline 4 & $\mathrm{G} 1 \mathrm{xP} 2$ & $\widehat{\mathrm{SUC}}=\overline{\mathrm{SUC}}=95.22$ & - \\
\hline 5 & $\mathrm{G} 2 \mathrm{xP} 2$ & $\widehat{\mathrm{SUC}}=\overline{\mathrm{SUC}}=96.55$ & - \\
\hline 6 & $\mathrm{G} 3 \mathrm{xP} 2$ & $\widehat{S U C}=\overline{\mathrm{SUC}}=97.11$ & - \\
\hline 7 & G1xP3 & $\widehat{\mathrm{SUC}}=\overline{\mathrm{SUC}}=95.11$ & - \\
\hline 8 & $\mathrm{G} 2 \mathrm{xP} 3$ & $\widehat{\mathrm{SUC}}=\overline{\mathrm{SUC}}=95.22$ & - \\
\hline 9 & G3xP3 & $\widehat{\mathrm{SUC}}=\overline{\mathrm{SUC}}=97.00$ & - \\
\hline 10 & G1xP4 & $\mathrm{SUC}=\overline{\mathrm{SU}} \overline{\mathrm{C}}=95.11$ & - \\
\hline 11 & $\mathrm{G} 2 \mathrm{xP} 4$ & $\widehat{\mathrm{SUC}}=\overline{\mathrm{SUC}}=93.22$ & - \\
\hline 12 & $\mathrm{G} 3 \mathrm{xP} 4$ & $\widehat{\mathrm{SUC}}=\overline{\mathrm{SUC}}=97.22$ & - \\
\hline
\end{tabular}

$* *$ significant at $1 \%$, and *significant at $5 \%$ probability by the $\mathrm{t}$ test.

\section{CONCLUSIONS}

The G3 dripper operating at pressures of 70 and $140 \mathrm{kPa}$ were the combinations that best attenuated biofilm clogging.

The linear regression and square root were the models that best represented the reduction in the uniformity of the effluent application as a function of the operating time of the drip irrigation sets.

The linear correlations denoted that calcium contents and total coliform population rates were the characteristics of the diluted landfill leachate that 
most affected the drip clogging process.

\section{REFERENCES}

$\begin{array}{lll}\text { ASSOCIAÇÃO } & \text { BRASILEIRA DE NORMAS } \\ \text { TÉCNICAS - ABNT. NBR ISO } 9261 .\end{array}$ Equipamentos de irrigação agrícola: emissores e tubos emissores: especificações e métodos de ensaio. São Paulo, SP: ABNT, 2006. 17 p.

BATISTA, R. O. et al. Modelos empíricos da irrigação localizada com esgoto sanitário tratado. Engenharia na Agricultura, Viçosa, v. 16, n. 3, p. $369-377,2008$.

BATISTA, R. O. et al. Taponamiento de goteros y del filtro de discos con agua residual sanitaria de uma laguna de maduración. Revista Facultad Nacional de Agronomía, Medellín, v. 62, n. 1, p. 4957-4966, 2009.

BATISTA, R. O. et al. Efeito das características do esgoto doméstico na uniformidade de aplicação de sistemas de irrigação por gotejamento. Revista Caatinga, Mossoró, v. 24, n. 4, p. 137-144, 2011 a.

BATISTA, R. O. et al. Influência de diferentes qualidades de esgoto doméstico na vazão de gotejadores. Revista Caatinga, Mossoró, v. 24, n. 3, p. $128-134,2011$ b.

BATISTA, R. O. et al. Obstrução e uniformidade de aplicação em sistemas de irrigação por gotejamento aplicando-se efluente da suinocultura. Revista Brasileira de Engenharia Agrícola e Ambiental, Campina Grande, v. 17, n. 7, p. 698-705, 2013.

BATISTA, R. O. et al. Modelos empíricos da aplicação de água residuária de suinocultura por gotejadores sob pressões de serviço. Irriga, Botucatu, v. 21, n. 4, p. 648-661, 2016.

BATISTA, R. O.; OLIVEIRA, A. F. M.; MESQUITA, F. O. Desempenho hidráulico de sistemas de irrigação por gotejamento operando com água residuária da suinocultura. Magistra, Cruz das Almas, v. 26, n. 1, p. 75-88, 2014.

BHATT, A. H. et al. Estimating landfill leachate BOD and COD based on rainfall, ambient temperature, and waste composition: Exploration of a MARS statistical approach. Environmental Technology \& Innovation, Lancaster, v. 8, n. 1, p. 1 $-16,2017$.

CAPRA, A.; SCICOLONE, B. Water quality and distribution uniformity in drip/trickle irrigation systems. Journal of Agricultural Engineering Research, London, v. 70, n. 4, p. 355-365, 1998.
CEARÁ. Resolução COEMA $\mathbf{n}^{0} \mathbf{2}$ de $\mathbf{2}$ de fevereiro de 2017. Dispõe sobre padrões e condições para lançamento de efluentes líquidos gerados por fontes poluidoras, revoga as Portarias SEMACE $\mathrm{n}^{\mathrm{o}} 154$, de 22 de julho de 2002 e $^{\mathrm{o}} 111$, de 05 de abril de 2011, e altera a Portaria SEMACE $\mathrm{n}^{\circ} 151$, de 21 de fevereiro de 2017. Diário Oficial do Estado do Ceará, Fortaleza, 2002. Disponível em: $<$ https://www.legisweb.com.br/legislacao/? $\mathrm{id}=337973>$. Acesso em: 28 dez. 2017.

COELHO, D. C. L. et al. Produção de capim elefante utilizando percolado de aterro sanitário. Bioscience Journal, Uberlândia, v. 31, n. 3, p. 830-840, 2015.

DAZHUANG, Y. et al. Biofilm structure and its influence on clogging in drip irrigation emitters distributing reclaimed wastewater. Journal of Environmental Sciences, Beijing, v. 21, n. 6, p. 834 $-841,2009$.

DURAN-ROS, M. et al. Effect of filter, emitter and location on clogging when using effluents. Agricultural Water Management, Amsterdam, v. 96, n. 1, p. 67-79, 2009.

EROGLU, S. et al. Bacterial application increased the flow rate of $\mathrm{CaCO}_{3}$-clogged emitters of drip irrigation system. Journal of Environmental Management, London, v. 98, n. 1, p. 37-42, 2012.

GUTIERREZ, K. G.; MATOS, A. T.; ROSSMANN, M. Influência da presença de camada de resíduos de construção civil na remoção de metais pesados em percolado recirculado de aterro sanitário. AmbiÁgua, Taubaté, v. 5, n. 2, p. 87-98, 2010.

LI, G. et al. Effects of average velocity on the growth and surface topography of biofilms attached to the reclaimed wastewater drip irrigation system laterals. Irrigation Science, New York, v.30, n. 2, p. 103-113, 2011

LIU, H.; HUANG, G. Laboratory experiment on drip emitter clogging with fresh water and treated sewage effluent. Agricultural Water Management, Amsterdam, v. 96, n. 5, p. 745-756, 2009.

MARQUES, B. C. D. et al. Desempenho de gotejadores operando com água residuária de laticínios em escala laboratorial. Irriga, Botucatu, v. 21, n. 1, 140-155, 2016.

MATOS, A. T.; CARVALHO, A. L.; AZEVEDO, I. C. D. Viabilidade do aproveitamento agrícola de percolados de resíduos sólidos urbanos. Revista Brasileira de Engenharia Agrícola e Ambiental, Campina Grande, v. 12, n. 4, p. 435-440, 2008.

MESQUITA, F. O. et al. Desempenho de 
gotejadores aplicando percolado de aterro sanitário diluído. Irriga, Botucatu, v. 21, n. 1, 156-171, $2016 \mathrm{a}$.

MESQUITA, F. O. et al. Drip units operating with dilute landfill leachate. Revista Caatinga, Mossoró, v. 29 , n. 1, 163-172, $2016 \mathrm{~b}$.

OLIVER, M. M. H.; HEWA, G. A.; PEZZANITI, D. Bio-fouling of subsurface type drip emitters applying reclaimed waterunder medium soil thermal variation. Agricultural Water Management, Amsterdam, v. 133, n. 1, p. 12-23, 2014.

PIMENTEL GOMES, F. Curso de estatística experimental. 15. ed. Piracicaba, SP: FEALQ, 2009. $451 \mathrm{p}$.

RICE, E. W.; BAIRD, R. B.; CLESCERI, A. D. Standard methods for the examination of water and wastewater. 22. ed. Washington: APHA, AWWA, WPCR, 2012. 1496 p.

SILVA, D. F. et al. Alteração química de solo cultivado com capim Tifton 85 (Cynodon spp.) e fertirrigado com percolado de resíduo sólido urbano. Acta Scientiarum. Technology, Maringá, v. 33, n. 3, p. 243-251, 2011.

SILVA, K. B. et al. Desempenho de gotejadores operando com efluente da castanha de caju sob distintas pressões de serviço. Revista Ceres, Viçosa, v. 60, n. 3 , p. 339-346, 2013.

SILVA, K. B. et al. Empirical models for performance of drippers applying cashew nut processing wastewater. Revista Caatinga, Mossoró, v. 29, n. 2, p. 405-414, 2016.

SILVA, L. P. et al. Desempenho de gotejadores autocompensantes com diferentes efluentes de esgoto doméstico. Revista Brasileira de Engenharia Agrícola e Ambiental, Campina Grande, v. 16, n. 5, p. 480-486, 2012.

TRIPATHI, V. K.; RAJPUT, T. B. S.; PATEL, N. Biometric properties and selected chemical concentration of cauliflower influenced by wastewater applied through surface and subsurface drip irrigation system. Journal of Cleaner Production, Amsterdam, v. 139, n. 1, p. 396-406, 2016.

YAN, D. et al. Biofilm structure and its influence on clogging in drip irrigation emitters distributing reclaimed wastewater. Journal of Environmental Sciences, Beijing, v. 21, n. 6, p. 834-841, 2009. 